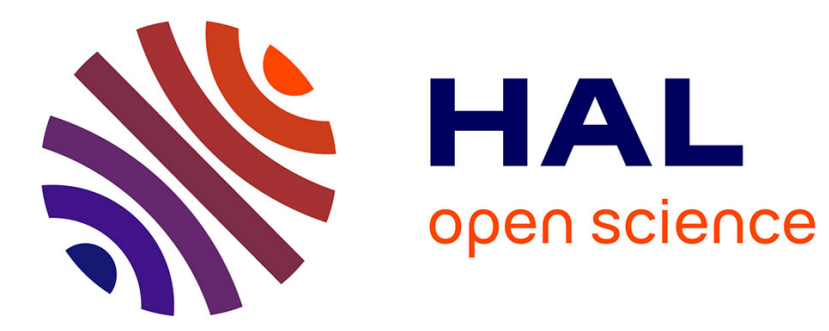

\title{
Light-Induced Metastable States in Oxalatenitrosylruthenium(II) and Terpyridinenitrosylruthenium(II) Complexes
}

Sylvie Ferlay, Helmut Schmalle, Giancarlo Francese, Helen Stoeckli-Evans, Mirco Imlau, Dominik Schaniel, Theo Woike

\section{To cite this version:}

Sylvie Ferlay, Helmut Schmalle, Giancarlo Francese, Helen Stoeckli-Evans, Mirco Imlau, et al.. LightInduced Metastable States in Oxalatenitrosylruthenium(II) and Terpyridinenitrosylruthenium(II) Complexes. Inorganic Chemistry, 2004, 43 (11), pp.3500-3506. 10.1021/ic0350178 . hal-02301503

\section{HAL Id: hal-02301503 \\ https://hal.science/hal-02301503}

Submitted on 25 Nov 2020

HAL is a multi-disciplinary open access archive for the deposit and dissemination of scientific research documents, whether they are published or not. The documents may come from teaching and research institutions in France or abroad, or from public or private research centers.
L'archive ouverte pluridisciplinaire HAL, est destinée au dépôt et à la diffusion de documents scientifiques de niveau recherche, publiés ou non, émanant des établissements d'enseignement et de recherche français ou étrangers, des laboratoires publics ou privés. 


\section{Light-Induced Metastable Electronic States in}

\section{Oxalatenitrosylruthenium(II) and}

\section{Terpyridinenitrosylruthenium(II) Complexes}

Sylvie Ferlay ${ }^{\prime \prime}$, Helmut W. Schmalle ${ }^{2}$, Giancarlo Francese', Helen Stoeckli-Evans ${ }^{3}$, Mirco Imlau ${ }^{4}$, Dominik Schaniels, and Theo Woikes

Departement für Chemie und Biochemie, Universität Bern, Freiestrasse 3, CH-3012

$$
\text { BERN, SWITZERLAND }
$$

Anorganisch Chemisches Institut, Universität Zürich, Winterthurerstrasse 190, CH8057 ZÜRICH, SWITZERLAND

Institut de Chimie, Université de Neuchâtel, Avenue de Bellevaux 51, CH-2007 NEUCHÂTEL, SWITZERLAND

Fachbereich Physik,Universität Osnabrück, Barbarastrasse 7, D-49069 OSNABRÜCK, DEUTSCHLAND

Institut für Mineralogie, Universität zu Köln, Zülpicherstrasse 49b, D-50674 KÖLN, DEUTSCHLAND

RECEIVED DATE (to be automatically inserted after your manuscript is accepted if required according to the journal that you are submitting your paper to) 
$†$ Present adress : Laboratoire de Tectonique Moléculaire du Solide, Institut Le Bel, 5ème Etage, 4, rue Blaise Pascal F- 67008 STRASBOURG CEDEX FRANCE ;

email : ferlay@chimie.u-strasbg.fr

Phone :00 33390241326

Fax : 0033390241325

\section{ABSTRACT}

Two extremely long - lived metastable states can be excited by irradiation with light in the blue-green spectral range at temperatures below $200 \mathrm{~K}$ in $\mathrm{Cs}_{2}\left[\mathrm{Ru}(\mathrm{ox})(\mathrm{NO}) \mathrm{Cl}_{3}\right]$, $[\mathrm{Ni}($ cyclam $)]\left[\mathrm{Ru}(\mathrm{ox})(\mathrm{NO}) \mathrm{Cl}_{3}\right] \cdot 3 \mathrm{H}_{2} \mathrm{O}$ and $[\mathrm{Ru}($ terpy $)(\mathrm{NO})(\mathrm{OH}) \mathrm{Cl}]\left[\mathrm{PF}_{6}\right]$. The crystal structures of the ground states, for the oxalate containing compounds, are presented and the influence of the atomic distances of the cations/anions is discussed with respect to the decay temperatures. The radiationless thermal decay of the metatstable states is detected by Differential Scanning Calorimetry (DSC) for the three compounds. Both metastable states decay exponentially in time under isothermal conditions. The excited states are energetically separated from the ground state by potential barriers given by the activation energy of the Arrhenius law. In $[\mathrm{Ni}($ cyclam $)]\left[\mathrm{Ru}(\mathrm{ox})(\mathrm{NO}) \mathrm{Cl}_{3}\right] \cdot 3 \mathrm{H}_{2} \mathrm{O}$ the enthalpy maximum of the thermal decay of SII appears at $182 \mathrm{~K}$, which is a high decay temperature for SII. The reason for this strong temperature shift compared to the other compounds could be due to the polarization effect of the $\mathrm{Ni}^{2+}$ on the electron density at the $\mathrm{Ru}$-site via the Cl-atom. 


\section{INTRODUCTION}

Since the discovery of extremely long-lived light-induced metastable states in sodiumnitroprusside, $\mathrm{Na}_{2}\left[\mathrm{Fe}(\mathrm{CN})_{5} \mathrm{NO}\right] \cdot 2 \mathrm{H}_{2} \mathrm{O}[\mathrm{NaNP}]$, by Hauser et al.', a lot of further complexes containing Ruthenium(II) ${ }^{2,34}$ Osmium(II) ${ }^{5}$ and Nickel(II) ${ }^{6}$ have been found with similar photo-physical behavior. Characteristic for all compounds is the nitrosyl ligand NO, so that the existence of the metastable states does not depend on the presence of the $3 \mathrm{~d}-$, $4 \mathrm{~d}-$ or 5d-electrons of the central metal atoms, but mainly on the optical and electronic properties of the NO ligand. The empty antibonding $\pi^{*}(\mathrm{NO})$ orbital lies energetically between the empty and filled $d$ states of the metal atom. Two metastable states SI and SII can be excited by irradiation with light of the corresponding energy difference between the HOMO d-state $\left(2 b_{2}\right.$, $\left.\mathrm{d}_{\mathrm{xy}}\right)$ and the LUMO $\pi^{*}(\mathrm{NO})$-orbital (7e): $\Delta \mathrm{E}=\mathrm{E}\left(\mathrm{d}_{\mathrm{xy}}\right)-\mathrm{E}\left(\pi^{*}(\mathrm{NO})\right)$. ' The metastable states are separated by potential barriers from the ground state (GS) and from each other. The barrier height is responsible for the lifetimes of these states. A lifetime of $\tau>10^{8}$ seconds can be realized at room temperature, if the activation energy $\mathrm{E}_{\wedge}$ exceeds $1.0 \mathrm{eV}$. These excited states can be detected with Differential Scanning Calorimetry (DSC), Infrared/Raman spectroscopy $^{9}$, Moessbauer spectroscopy ${ }^{10}$, EXAFS $^{6}$, neutron" ${ }^{11}$ and X-ray diffraction ${ }^{12}$. The transfer of both states into the ground state is possible by irradiation with light corresponding to the energy difference of SI or SII and the $\pi^{*}(\mathrm{NO})$ orbital, $\Delta \mathrm{E}=\mathrm{E}(\mathrm{SI}, \mathrm{SII})-\mathrm{E}\left(\pi^{*}(\mathrm{NO})\right)$, or by heating the system. The radiationless thermal decay is a first order reaction and can be described by the Arrhenius law. Otherwise, by irradiation with light in the spectral range of the absorption band of SI, the metal-nitrosyl compounds can be partially transferred from SI into SII. It is also possible to go from SII into $\mathrm{SI}^{{ }^{\mathrm{a}}}$. This points to the reversibility of the population cycles for these metal-nitrosyl compounds and shows that they are suitable for information storage. Since there are strong differences in the refractive indices of about $\Delta \mathrm{n} \sim$ $10^{-2}$ between SI, SII and GS, these materials can be used for information storage with very high capacity by employing volume holographic methods ${ }^{13}$. For this application it is necessary 
to get substances in which the new states are stable at above room temperature with sufficient population of about $2 \%$ at least.

Different strategies can be used for obtaining such materials: (i) modification of the already known compound $\mathrm{Na}_{2}\left[\mathrm{Fe}(\mathrm{CN})_{5} \mathrm{NO}\right] \cdot 2 \mathrm{H}_{2} \mathrm{O}$ by variation of the cation. It was found in an earlier study, that the exchange of the cation (by alkali or p-block metals) leads to an increase of the decay temperature of SI from $186 \mathrm{~K}$ to $223 \mathrm{~K}$, while the population of the metastable states decrease ${ }^{14}$. The maximum population for $\mathrm{SI}$ of $50 \%$ is reached in $\mathrm{Na}_{2}\left[\mathrm{Fe}(\mathrm{CN})_{5} \mathrm{NO}\right] \cdot 2 \mathrm{H}_{2} \mathrm{O}$ and $\mathrm{Li}_{2}\left[\mathrm{Fe}(\mathrm{CN})_{5} \mathrm{NO}\right] \cdot 4 \mathrm{H}_{2} \mathrm{O}$. (ii) changing the metal center (i.e. $\mathrm{Ru}$, Os instead of $\mathrm{Fe}$ ) and its environment $\left(\mathrm{Cl}, \mathrm{NH}_{3}\right.$, etc. as ligands instead of $\left.\mathrm{CN}\right)$. In the last years, Morioka et al. ${ }^{4}$ and Coppens et al. ${ }^{\text {s5 }}$ presented new ruthenium nitrosyl compounds, in which SI is stable at about $270 \mathrm{~K}$, but with a very low population $(\approx 2 \%)$.

We have prepared and investigated new ruthenium-nitrosyl compounds $\mathrm{Cs}_{2}\left[\mathrm{Ru}(\mathrm{ox})(\mathrm{NO}) \mathrm{Cl}_{3}\right],[\mathrm{Ni}($ cyclam $)]\left[\mathrm{Ru}(\mathrm{ox})(\mathrm{NO}) \mathrm{Cl}_{3}\right] \cdot 3 \mathrm{H}_{2} \mathrm{O}$ and $[\mathrm{Ru}($ terpy $)(\mathrm{NO})(\mathrm{OH}) \mathrm{Cl}]\left[\mathrm{PF}_{6}\right]^{16}$, in order to analyze the influence of the cis- and trans-ligands and the metal-organic Nicomplex on the decay temperature and the degree of the population. We present the crystallographic structures for the compounds containing the oxalate ligand, and for the three compounds, the dynamics of the thermal decay of SI and SII, measured by Differential Scanning Calorimetry. The photophysical results will be discussed with respect to the structural details.

\section{EXPERIMENTAL SECTION}

\section{Synthesis}

All chemicals were of reagent grade and were used as commercially obtained. Terpy (terpy $=2,262$ " terpyridine) was purchased from Aldrich Chemicals, $[\mathrm{Ni}($ cyclam $)] \mathrm{Cl}_{2} \cdot 2 \mathrm{H}_{2} \mathrm{O}$

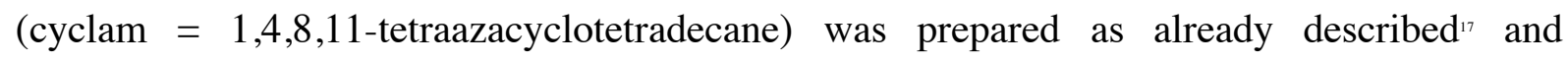
$\mathrm{K}_{2}\left[\mathrm{Ru}(\mathrm{NO}) \mathrm{Cl}_{5}\right]$ was prepared according to the method described in the literature ${ }^{18}$. Generally, 
electrochemistry ${ }^{19}$ or the use of chemical oxidizing agent ${ }^{20}$ are employed to prepare ruthenium nitrosyl compounds, but we preferred addition reactions ${ }^{21}$, which allow the control of the obtained products. All the described compounds are stable in air.

\section{$\mathrm{Cs}_{2}\left[\operatorname{Ru}(\mathrm{ox})(\mathrm{NO}) \mathrm{Cl}_{3}\right](\mathbf{1})$}

A $10 \mathrm{ml}$ aqueous solution of $\mathrm{H}_{2} \mathrm{C}_{2} \mathrm{O}_{4}(6 \mathrm{mmol})$ was added to a $10 \mathrm{ml}$ solution containing 3 mmol of $\mathrm{K}_{2}\left[\mathrm{Ru}(\mathrm{NO}) \mathrm{Cl}_{5}\right]$. We adjusted the $\mathrm{pH}$ of this suspension to 3, with a concentrated $\mathrm{KOH}$ solution. Then the solution was stirred 3 hours under reflux. During this operation, we adjusted the $\mathrm{pH}$ three times to 3. At the end, no change of the $\mathrm{pH}$ was observed. After cooling this clear red solution, it was added $5 \mathrm{ml}$ of a saturated solution of aqueous $\mathrm{CsCl}$, then it was allowed to stand at room temperature to evaporate. After several days dark red crystals of the following formula, $\mathrm{Cs}_{2}\left[\mathrm{Ru}\left(\mathrm{C}_{2} \mathrm{O}_{4}\right)(\mathrm{NO}) \mathrm{Cl}_{3}\right]$, suitable for X-ray diffraction, appeared. They were collected by filtration, washed with cold water and dried under vacuum. Analytic Calculation for $\mathrm{C}_{2} \mathrm{NO}_{5} \mathrm{Cl}_{3} \mathrm{Cs}_{2} \mathrm{Ru}: \mathrm{C}, 40.59 \% ; \mathrm{Cl}, 18.01 \% ; \mathrm{N}, 2.36 \%$. Found: C, $41.30 ; \mathrm{Cl}, 18.55 \%$; $2.30 \%$.

\section{$[\mathrm{Ni}($ cyclam $)]\left[\mathrm{Ru}(\mathrm{ox})(\mathrm{NO}) \mathrm{Cl}_{3}\right] \cdot 3 \mathrm{H}_{2} \mathrm{O}(2)$}

It was obtained using the same procedure as for (1). After cooling the solution, a saturated aqueous solution of $[\mathrm{Ni}($ cyclam $)] \mathrm{Cl}_{2} \cdot 2 \mathrm{H}_{2} \mathrm{O}$ was added. After several days, red-brown crystals of the following formula : $\left[\mathrm{Ni}\left(\mathrm{N}_{4} \mathrm{C}_{10} \mathrm{H}_{24}\right)\right]\left[\mathrm{Ru}\left(\mathrm{C}_{2} \mathrm{O}_{4}\right)(\mathrm{NO}) \mathrm{Cl}_{3}\right] \cdot 3 \mathrm{H}_{2} \mathrm{O}$, suitable for $\mathrm{X}$-ray diffraction, appeared. Analytic Calculation for $\mathrm{C}_{12} \mathrm{H}_{30} \mathrm{Cl}_{3} \mathrm{~N}_{5} \mathrm{NiO}_{8} \mathrm{Ru}: \mathrm{C}, 22.55 \% ; \mathrm{H}, 4.70 \%$; $\mathrm{Cl}$, $16.68 \%$; N, $10.96 \%$. Found : C, $23.40 \% ; \mathrm{H}, 4.30 \%$; Cl, $16.50 \%$; , $11.15 \%$.

\section{$\left[\mathrm{Ru}(\right.$ terpy $)(\mathrm{NO})(\mathrm{OH}) \mathrm{Cl}_{\mathrm{PF}}(\mathrm{3})$}

A new preparation of this compound is presented here.

A $10 \mathrm{ml}$ alcoholic solution of terpyridine ( $3 \mathrm{mmol}$ in methanol) was added to a $10 \mathrm{ml}$ aqueous solution containing $3 \mathrm{mmol}$ of $\mathrm{K}_{2}\left[\mathrm{Ru}(\mathrm{NO}) \mathrm{Cl}_{5}\right]$. We adjusted the $\mathrm{pH}$ of this suspension to 6 , with a concentrated $\mathrm{KOH}$ solution. Then the solution was stirred 3 hours under reflux. During this operation, we adjusted the $\mathrm{pH}$ three times to 6 . At the end, no change of the $\mathrm{pH}$ 
was observed. After cooling this clear red solution, it was added $5 \mathrm{ml}$ of a saturated methanolic solution of $\mathrm{KPF}_{6}$, then it was allowed to stand at room temperature to evaporate. After a couple of days, red crystals of the following formula : $\left[\mathrm{Ru}\left(\mathrm{C}_{15} \mathrm{~N}_{3} \mathrm{H}_{11}\right)(\mathrm{NO})(\mathrm{OH}) \mathrm{Cl}\right] \mathrm{PF}_{6}$ appeared. They were collected by filtration, washed with cold water and dried under vacuum. Analytic Calculation for $\mathrm{C}_{15} \mathrm{H}_{12} \mathrm{ClF}_{6} \mathrm{~N}_{4} \mathrm{O}_{2} \mathrm{PRu}: \mathrm{C}, 32.04 \% ; \mathrm{H}, 2.14 \% ; \mathrm{Cl}, 6.32 \%$;, $9.97 \%$. Found : C, $33.5 \% ; \mathrm{H}, 2.2 \% ; \mathrm{Cl}, 6.5 \% ; \mathrm{N}, 10.2 \%$. We performed the X-ray diffraction on single crystals, and obtained a comparable resolution of the structure as proposed in the literature ${ }^{16}$.

\section{Determination of the structure}

Selected crystallographic data and structure determination parameters for compounds (1) and (2) are given in Table 1, together with those of (3), for comparison. For all the compounds, the data were collected in the ground state (GS) of the molecules. Intensity data were collected at $223 \mathrm{~K}$ on a Stoe Image Plate Diffraction System equipped with a $\phi$ circle, using $\mathrm{MoK}_{\alpha}$ graphite-monochromated radiation $(\lambda=0.71073 \AA)$ for (1) and at room temperature using an Enraf-Nonius CAD-4 diffractometer with graphite-monochromated $\operatorname{MoK}_{\alpha}$ radiation $(\lambda=0.71073 \AA)$ for (2) and (3).

A dark red square-pyramidal crystal of (1) with approximate dimensions $0.40 \times 0.30 \times 0.10$ $\mathrm{mm}^{3}$ was chosen for the X-ray structure determination. A triclinic unit cell was determined from 25 indexed reflections in the range $3.0^{\circ}<2 \theta<52.0^{\circ}$, with an image plate distance of 70 $\mathrm{mm}$, a $\phi$ range of $0-185^{\circ}$ and an increment of $1^{\circ}$. The number of intensity data measured was 3955 (hkl range +/- $8,+/-8-14-15$ ). The space group was $\mathrm{P} \overline{1}$, using the Patterson interpretation routine of SHELXS-972. Refinement was carried out by full-matrix leastsquares techniques, with SHELXL-9723 (see Table 1). An empirical absorption correction was applied using the DIFABS routine in the program PLATON,${ }^{24}$ transmission factors $\mathrm{min} / \mathrm{max}=$

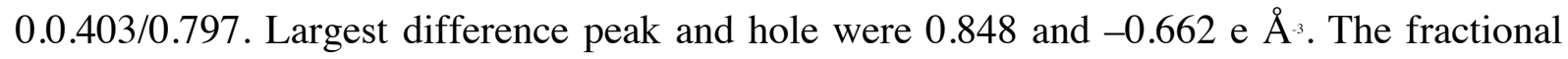


coordinates and the isotropic displacement parameters are listed in Table 2, and selected bond distances and angles are shown in Table 3.

A brown red square-pyramidal crystal of (2) with approximate dimensions of $0.36 \times 0.20 \mathrm{x}$ $0.06 \mathrm{~mm}^{3}$ was chosen for the X-ray structure determination. A triclinic unit cell was determined from 25 indexed reflections in the range $14.12^{\circ}<2 \theta<25.9^{\circ}$. The number of intensity data measured was 7240 (hkl range $+/-12,+/-14,0-21)$. Intensities were corrected for Lorentz-, polarization- and absorption-effects with the MolEN program package ${ }^{25}$. The space group was P-1, using the Patterson interpretation routine of SHELXS-97. Refinement was carried out by full-matrix least-squares techniques, with SHELXL-97 (see Table 1). Due to the relatively weak diffracting crystal, hydrogen atomic positions were calculated at distances of $0.93 \AA$ from carbon atoms and were fixed by using a rigid model in the refinemement. Largest difference peak and hole were 1.009 and -0.836 e $\AA^{-3}$. In Table 4 and table 5 the fractional coordinates and selected bond lengths are presented for compound (2). The atomic coordinates for all atoms, bond distances and angles are available in the supplementary material.

\section{Differential Scanning Calorimetry}

The samples (single crystals) for DSC measurements were ground to thin plates with a thickness of about $0.3 \mathrm{~mm}$ and were irradiated with unpolarized light. The irradiation was performed with a metal vapor lamp (HMI 575), filtered to the spectral range of $410-500 \mathrm{~nm}$ using an intensity of $200 \mathrm{~mW} / \mathrm{cm}^{2}$. The total exposure was $\mathrm{Q}=2800 \mathrm{Ws} / \mathrm{cm}^{2}$. The temperature was kept constant at $\mathrm{T}=100 \mathrm{~K}$. The radiationless decay of SI and SII is detected by a modified DSC-apparatus (Mettler: DSC 30, TA 2000), which is equipped with two quartz windows inside and outside of the furnace for the irradiation of the samples with light. The irradiated sample is heated with constant velocity $\mathrm{q}[\mathrm{K} / \mathrm{min}]$ during detection of the exothermal heat flow $\dot{H}[\mathrm{~mW}], \dot{H}=\frac{d H}{d t}$, which is the time derivative of the enthalpy $\mathrm{H}$ and $\dot{H}=\mathrm{q} \mathrm{dH} / \mathrm{dT}$ is the temperature derivation. 
In all spectra we have subtracted the heat flow of the unirradiated sample, measured before and after the irradiation, in order to get only the exothermal heat flow of SI and SII. From the peak integration we get the enthalpy $\mathrm{H}$, which is proportional to the population of the metastable states:

$$
H=\int_{T_{0}}^{T_{E}} \dot{H} d t^{\prime}=1 / \mathrm{q}^{\mathrm{a}} \mathrm{d}^{\prime}
$$

$\mathrm{T}_{\mathrm{o}}$ and $\mathrm{T}_{\mathrm{E}}$ indicate the boundaries for the integration. The isothermal decay can be fitted by an exponential function, so that we can evaluate all spectra using the Arrhenius law ${ }^{\text {ta }}$. Due to the mono exponential decay, the reaction order is $n=1$ (first order reaction) and we can fit the spectra using a modification of our earlier fit function ${ }^{8}$ :

$\stackrel{4}{\mathscr{t}}$

where the activation energy $\mathrm{E}_{\mathrm{A}}$ and the frequency factor $\mathrm{Z}$ are the adjustable parameters. $\mathrm{H}$ is the integrated enthalpy of the whole peak and $\mathrm{k}_{\mathrm{B}}$ is the Boltzmann constant. In all spectra the dots correspond to the experimental data and the solid lines to the fits.

In this case the decay temperature is defined as the peak maximum in the heat flow $v s$. temperature at a certain heating rate. The existence of the maximum is a result of the dynamic measurement with a heating rate $\mathrm{q} \neq 0$.

\section{RESULTS}

\section{A. Description of the structures}

Compounds (1) and (2) have the same anion in the unit cell, $\left[\mathrm{Ru}(\mathrm{ox})(\mathrm{NO}) \mathrm{Cl}_{3}\right]^{2}$, with analogous distances and geometry. Thus, we only present structural details of compound (1), and compound (2) will only be briefly described in a further paragraph. The nature of the 
counter cation induces changes in the orientation of the molecules in the unit cell, and consequently in the photophysical properties of the compounds.

\section{(1) $\mathrm{Cs}_{2}\left[\mathrm{Ru}(\mathrm{ox})(\mathrm{NO}) \mathrm{Cl}_{3}\right]$}

The structure of (1) consists of $\left[\mathrm{Ru}(\mathrm{NO})\left(\mathrm{C}_{2} \mathrm{O}_{4}\right) \mathrm{Cl}_{3}\right]^{2}$. anions, which are well separated from the $\mathrm{Cs}^{+}$cations. The asymmetric unit, along with the atomic numbering schemes is shown in Figure 1. Tables 2 and 3 summarize the atomic fractional coordinates and selected bond lengths and angles for (1). The $\left[\mathrm{Ru}(\mathrm{ox})(\mathrm{NO}) \mathrm{Cl}_{3}\right]^{2}$ units are also arranged anti-parallel along the [111] direction, as shown in the crystal packing in Figure 2. All the distances are given in supplementary material.

The ruthenium centers are in a distorted octahedral environment with one oxygen, from the oxalate ligand and the nitrogen of the nitrosyl ligand in axial positions; the equatorial plane being filled with three chlorine atoms and the other oxygen atom from the oxalate. The $\mathrm{Ru}-\mathrm{O}$ distances are 2.021(3) and 2.044(3) $\AA$ for $\mathrm{Ru}-\mathrm{O}(3)$ and $\mathrm{Ru}-\mathrm{O}(2)$, respectively, which is in accordance with the distances found in the corresponding trisoxalato complexes ${ }^{26}$. The bridging oxalate ligands are virtually planar and they have bond distances and angles within normal limits. The Ru-N(1) distance is equal to $1.746(4) \AA$, in accordance with the Ru-N distance found in other ruthenium nitrosyl compounds ${ }^{27}$. The $\mathrm{Ru}-\mathrm{Cl}$ average distance is equal to $2.3615(3) \AA$, which is typical, as well as the $\mathrm{N}(1)-\mathrm{O}(1)$ with $1.131(5) \AA$. The linearity of the $\mathrm{Ru}-\mathrm{N}-\mathrm{O}$ linkages is strongly indicative of the nitrosyl ligand bonding as $\mathrm{NO}^{+}$and thus, the oxidation state of the ruthenium centers is $+\mathrm{II}$.

The environment of both cesium cations consists of ten atoms : chlorine atoms and oxygen atoms from the oxalate ligand. These $\mathrm{Cs}-\mathrm{O}$ or $\mathrm{Cs}-\mathrm{Cl}$ average distances, given in Table 3 , are particularly long (about 3.3 and 3.6 $\AA$ ), and can not reveal a strong interaction between the cesium and the oxygen or chlorine atom. This is different from what was observed in other oxalate compounds, which contain alkali cations like $\mathrm{Na}^{+}$for example, where the $\mathrm{Na}-\mathrm{O}$ distance is $2.320(6) \AA^{28}$. 


\section{(2) $[\mathrm{Ni}($ cyclam $)]\left[\mathrm{Ru}(\mathrm{ox})(\mathrm{NO}) \mathrm{Cl}_{3}\right] \cdot 3 \mathrm{H}_{2} \mathrm{O}$}

Only the packing cell and the geometry of the cation are discussed here. The $\left[\mathrm{Ru}(\mathrm{ox})(\mathrm{NO}) \mathrm{Cl}_{3}\right]^{2}$ units are antiparalelly arranged along the $b$ axis. A view of the packing is shown in the Figure 3. Three molecules of the crystal water are present in the lattice.

The $\left[\mathrm{Ni}^{1}(\text { cyclam })\right]^{2+}$ counter ion is quasi planar. The distances in the $\left[\mathrm{Ni}^{\mathrm{I}}(\mathrm{cyclam})\right]^{2+}$ cations are comparable to the ones found in the free cation ${ }^{29}$. The environment of the nickel ions is a strongly distorted octahedron as is evident from the elongated distances to the axial positions: $\mathrm{Ni}-\mathrm{O}(22)$ or $\mathrm{Ni}-\mathrm{O}(21)$ distances are 3.125(2) and 3.528(2) $\AA$, respectively. The $\mathrm{Ni}-\mathrm{Cl}(2)$ distance is $3.026(2) \AA$, the $\mathrm{Ru}-\mathrm{Cl}(2)$ distance is $2.3547(12) \AA$, and the $\mathrm{Ru}-\mathrm{Ni}$ distance is $4.89 \AA$ A. Hydrogen bonding between the water molecules and the oxalate ligands occurs since the $\mathrm{H}(11)-\mathrm{O}(12)$ distance is $1.908(8) \AA$.

\section{$[$ Ru(terpy)(NO)(OH)CI]PF。}

The structure of (3) cis in accordance with the one already published ${ }^{16}$.

\section{B. Photophysical properties}

The light-induced metastable states SI, SII are found in all three Ru-compounds. However, in comparison with $\mathrm{Na}_{2}\left[\mathrm{Fe}(\mathrm{CN})_{5} \mathrm{NO}\right] \cdot 2 \mathrm{H}_{2} \mathrm{O}$ (NaNP) the population is very low. In Figure 4, the heat flow of the thermal decay of (1), (2) and (3) is shown in the range of $120-220 \mathrm{~K}$.

For $\mathrm{Cs}_{2}\left[\mathrm{Ru}(\mathrm{ox})(\mathrm{NO}) \mathrm{Cl}_{3}\right]$, (1) the maxima of the decay temperatures, detected with a heating velocity of $\mathrm{q}=5 \mathrm{~K} / \mathrm{min}$, are found at $\mathrm{T}(\mathrm{SI})=(198 \pm 1) \mathrm{K}$ and $\mathrm{T}(\mathrm{SII})=(161 \pm 1) \mathrm{K}$. Assuming the same behavior between enthalpy $\mathrm{H}$ and population as found in $\mathrm{NaNP}^{7 \mathrm{a}}$ (i.e. an enthalpy of $1 \mathrm{~kJ} / \mathrm{mol}$ corresponds to $1 \%$ population), we find a population of $1.3 \%$ for SI and of $0.6 \%$ for SII, given by the enthalpies of $\mathrm{H}(\mathrm{SI})=(1.3 \pm 0.2) \mathrm{kJ} / \mathrm{mol}$ and $\mathrm{H}(\mathrm{SII})=(0.6 \pm 0.3) \mathrm{kJ} / \mathrm{mol}$, respectively. The isothermal decay can be fitted by a pure exponential function so that the reaction order is $\mathrm{n}=1$ and the Arrhenius law is valid. From the evaluation of the temperature dependence of the dynamical measurements of $\dot{H}$ by the Arrhenius law the activation 
energies $\mathrm{E}(\mathrm{SI})=(0.60 \pm 0.05) \mathrm{eV}, \mathrm{E}(\mathrm{SII})=(0.46 \pm 0.05) \mathrm{eV}$ and the frequency factors $\mathrm{Z}(\mathrm{SI})=$ $(2.5 \pm 1.0) * 10^{13} \mathrm{~s}^{-1}, \mathrm{Z}(\mathrm{SII})=(5 \pm 1) * 10^{12} \mathrm{~s}^{-1}$ are obtained. From the pure exponential decay under isothermal conditions we can clearly deduce that the excited $\left[\mathrm{Ru}(\mathrm{NO})(\mathrm{ox}) \mathrm{Cl}_{3}\right]^{2-}$ anions are completely independent from each other and they have no interaction with those in the ground state. By population of the metastable states we have only changed the number density in GS, SI or SII.

Substituting the cation $\mathrm{Cs}^{+}$against $\left[\mathrm{Ni}^{\mathrm{i}}(\text { cyclam })\right]^{2+}$ in (2), the decay temperature of SI increases a little to $\mathrm{T}(\mathrm{SI})=(201 \pm 1) \mathrm{K}$. But, as shown in Figure $4 \mathrm{~b}$, the decay of SII is significantly increased to $\mathrm{T}(\mathrm{SII})=(182 \pm 1) \mathrm{K}$, which is a high decay temperature of SII. The enthalpies or populations are very low: $\mathrm{H}(\mathrm{SI})=(0.8 \pm 0.2) \mathrm{kJ} / \mathrm{mol}, \mathrm{H}(\mathrm{SII})=(0.4 \pm 0.2) \mathrm{kJ} / \mathrm{mol}$. The activation energies and frequency factors have an amount of $\mathrm{E}(\mathrm{SI})=(0.55 \pm 0.05) \mathrm{eV}$, $\mathrm{E}(\mathrm{SII})=(0.44 \pm 0.05) \mathrm{eV}, \mathrm{Z}(\mathrm{SI})=(6 \pm 1) * 10^{11} \mathrm{~s}^{-1}, \mathrm{Z}(\mathrm{SII})=(2 \pm 1) * 10^{10} \mathrm{~s}^{-1}$

The terpyridine compound (3) was prepared for comparison with $\mathrm{K}_{2}\left[\mathrm{Ru}\left(\mathrm{NO}_{2}\right)_{4}(\mathrm{OH})(\mathrm{NO})\right]$. In the latter we have found ${ }^{2 a}$ a significant shift of SII to higher temperatures compared to NaNP, but we could not decide, whether it is a result of the $(\mathrm{OH})$-ligand trans to the NO or of the equatorial $\left(\mathrm{NO}_{2}\right)$ ligands. As shown in Figure 4c the decay temperatures of SI and SII of $[\mathrm{Ru}($ terpy $)(\mathrm{OH})(\mathrm{NO}) \mathrm{Cl}]\left[\mathrm{PF}_{6}\right](3)$ decrease to $\mathrm{T}(\mathrm{SI})=(180 \pm 1) \mathrm{K}$ and $\mathrm{T}(\mathrm{SII})=(147 \pm 1) \mathrm{K}$, compared with $\mathrm{T}(\mathrm{SI})=(199 \pm 1) \mathrm{K}$ and $\mathrm{T}(\mathrm{SII})=(166 \pm 1) \mathrm{K}$ of $\mathrm{K}_{2}\left[\mathrm{Ru}\left(\mathrm{NO}_{2}\right)_{4}(\mathrm{OH})(\mathrm{NO})\right]$ Therefore, the $(\mathrm{OH})$ ligand seems not to be responsible for the shift of the decay temperatures. The increase is produced by the equatorial $\left(\mathrm{NO}_{2}\right)$-ligands.

The activation energies of $(3)$ are: $\mathrm{E}(\mathrm{SI})=(0.44 \pm 0.05) \mathrm{eV}, \mathrm{E}(\mathrm{SII})=(0.46 \pm 0.05) \mathrm{eV}$. The frequency factors differ by about four orders of magnitude, which results in a much smaller line width of SII: $\mathrm{Z}(\mathrm{SI})=(3 \pm 1) * 10^{10} \mathrm{~S}^{-1}, \mathrm{Z}(\mathrm{SII})=(1.5 \pm 1.0) * 10^{14} \mathrm{~s}^{-1}$.

Again the enthalpy or population is very low: $\mathrm{H}(\mathrm{SI})=(1.2 \pm 0.2) \mathrm{kJ} / \mathrm{mol}, \mathrm{H}(\mathrm{SII})=(0.9 \pm 0.2)$ $\mathrm{kJ} / \mathrm{mol}$. A significant overlap of the decays is only found in the $[\mathrm{Ni}(\mathrm{Cyclam})]\left[\mathrm{Ru}\left(\mathrm{C}_{2} \mathrm{O}_{4}\right) \mathrm{Cl}_{3} \mathrm{NO}\right] \cdot 3 \mathrm{H}_{2} \mathrm{O}(3)$ complex. For the integration of the peaks a linear 
base line at $\dot{H}=0$ is used, since the subtraction of the irradiated and unirradiated sample gives zero heat flow before - between - and after the decay regions. There is no detectable structural phase transition in the ground state or induced by the irradiation.

\section{DISCUSSION}

All Fe- and Ru- nitrosyl compounds, in which SI and SII can be excited, show the same behavior of excitation and thermal decay: the irradiation wavelength is determined by the energetic difference between the empty $\pi * \mathrm{NO}$ orbital and the occupied mainly d-states of the metallic atom. At every population value, the new states are stable below the decay temperatures, so that the transferred compounds in ground state, SI and SII are independent from each other. This is also confirmed by the pure exponential isothermal decay with the reaction order $n=1$. The stored energy of both states is released to the lattice. The potential barriers can be calculated using Arrhenius' law. Therefore, the physical background of the metastable states in the Fe and Ru nitrosyl compounds is identical. It is possible to shift the decay temperatures of SI and SII towards room temperature by variation of the ligands ${ }^{4.15}$, whereby the underlying physical details of this potentiality remains unknown, but we see general trends:

1) As shown in this article the existence of SI and SII seems to be independent from the fact, whether the ruthenium complex is an anion or a cation, so that the formal total charge can be negative or positive, i.e. $\left[\mathrm{Ru}(\mathrm{NO})\left(\mathrm{C}_{2} \mathrm{O}_{4}\right) \mathrm{Cl}_{3}\right]^{2}$ (1) and (2) or $[\mathrm{Ru}($ terpy $)(\mathrm{NO}) \mathrm{OH}) \mathrm{Cl}]^{1+}(3)$. The main point is that formally $\mathrm{Ru}^{2+}$ and $(\mathrm{NO})^{+}$are present, which guarantee an efficient charge transfer transition from the d-states of the central atom into the $\pi^{*} \mathrm{NO}$-orbital.

2) We assume that the temperature, where a significant decay of the metastable states (decay temperature) can be detected, depends on the amount of electron density in the $\pi^{*} \mathrm{NO}$-orbital, and on the nature of the chelating ligand. Therefore we have prepared and 
investigated the compounds (1), (2), and (3) in order to introduce the ligand $\mathrm{C}_{2} \mathrm{O}_{4}$ with its closed ringlike structure. However, we found that this ligand has no significant influence on the lifetime of the metastable states. As already reported, it seems that ligands like O- and $\mathrm{N}$-donor ligands (oxalate, ethylenediamine, terpyridine, ...) are poor $\pi$-bonding and more $\sigma$-bonding, and they present the ability to give metastable states with high thermal stability ${ }^{\star c}$, as summarized in table 4 , where the activation energy $E_{\AA}$ and frequency factor $\mathrm{Z}$ for the states SI and SII of some metal nitrosyl compounds are presented. Since the liftime $\tau$ is given by $\tau=Z \exp \left(\mathrm{E}_{\curvearrowright} / \mathrm{k}_{\mathrm{B}} \mathrm{T}\right)$ at a certain temperature $\mathrm{T}$, the high thermal stability is determined by a high activation energy $E_{\wedge}$ and a low frequency factor Z. Fig. 5 shows the temperature dependence of the lifetimes of SI/SII exemplarily for $[\mathrm{Ni}($ cyclam $)]\left[\mathrm{Ru}(\mathrm{ox})(\mathrm{NO}) \mathrm{Cl}_{3}\right] \cdot 3 \mathrm{H}_{2} \mathrm{O}$ (2). In the temperature range $90 \mathrm{~K}-330 \mathrm{~K}$ the lifetimes drop from thousands of years down to mili- and microseconds. In Table 4 we compare our results with literature results for various $\mathrm{Ru}$-compounds. One finds that the frequency factor $\mathrm{Z}$ varies by over ten orders of magnitude for SI, whereas $\mathrm{E}_{\mathrm{A}}$ varies by only a factor of about $2.5(0.27 \mathrm{eV}$ to $0.7 \mathrm{eV})$, so that the variation of $\mathrm{Z}$ is the more important contribution to the shift of the thermal stability. Therefore the compounds (1), (2), and (3) have no significant higher thermal decay temperatures compared with the other compounds listed in Table 4. The values for $\mathrm{E}_{\wedge}$ and $\mathrm{Z}$ were obtained from a fit using Arrhenius' law for the decay of the metastable states. In order to interpret the physical origin of the parameters, we inspected also the Eyring equation, which allows a more detailed analysis of the decay processes. In the Eyring equation the intermediate states are taken into account for the description of the decay process: SI/SII $->$ intermediate states $->$ GS. One obtains for the frequency factor $\mathrm{Z}=\left(\mathrm{k}_{\mathrm{B}} \mathrm{T} / \mathrm{h}\right) \exp (\Delta \mathrm{S} / \mathrm{R})$, where $\mathrm{h}$ is Planck's constant, $\mathrm{R}$ is the molar gas constant, and $\Delta \mathrm{S}$ is the change in entropy during the decay process. The activation energy $E_{\wedge}$ corresponds mainly to the activation enthalpy $E_{A}=\Delta H$. The frequency factor $Z$ is linearly dependent on the temperature and is determined by the change in entropy, which describes the order of the system. Unfortunately, because of the low population obtained for the 
presented compounds, we are not able to determine the values of $\Delta \mathrm{S}$. Following the model of Carducci et al..$^{30}$, which claim an isonitrosyl configuration (Fe-ON) for SI and an side on configuration of NO for SII $\left(\eta^{2}\right)$, the activation energy is composed mainly of two parts: (i) the breaking of the Ru-(NO) bond and (ii) the rotation of the NO. Rotational energies are of the order of $10^{-3} \mathrm{eV}$, so that they can be neglected compared to the binding energies. In the Eyring description the large variation of the frequency factor $\mathrm{Z}$ for the different $\mathrm{Ru}-$ compounds is due to the change in entropy $\Delta \mathrm{S}$, which describes the change in order of the system. Therefore there must be a large range of variation with respect to the structural or electronic ordering between SI, SII, and GS.

3) The decay temperatures of SI and SII depend on the environment in which the complex is embedded. The highest decay temperature of SII $(182 \mathrm{~K})$ has been found in $[\mathrm{Ni}($ cyclam $)]\left[\mathrm{Ru}(\mathrm{ox})(\mathrm{NO}) \mathrm{Cl}_{3}\right] \cdot 3 \mathrm{H}_{2} \mathrm{O}(2)$. The influence of the cation on the lifetime of SI/SII has been investigated systematically by Zöllner et al. ${ }^{14}$ for a large variety of cations in $\left[\mathrm{Fe}(\mathrm{CN})_{s} \mathrm{NO}\right]$-compounds. The longest lifetime (highest decay temperature with a heating rate of $5 \mathrm{~K} / \mathrm{min}$ ) was found for the cation $\mathrm{Cu}^{2+}$. In $\mathrm{Cu}_{2}\left[\mathrm{Fe}(\mathrm{CN})_{5} \mathrm{NO}\right] \cdot 2 \mathrm{H}_{2} \mathrm{O}$ the shortest $\mathrm{Cu}-\mathrm{Fe}$ distances are $3.458 \AA$ and $3.269 \AA$ bridged over the axial and equatorial cyano ligands $\mathrm{N}_{\mathrm{ax}}$ $\left(\mathrm{Cu}-\mathrm{N}_{\mathrm{ax}}=2.160 \AA\right)$ and $\mathrm{N}_{\mathrm{cq}}\left(\mathrm{Cu}-\mathrm{N}_{\mathrm{cq}}=1.976 \AA\right)^{31}$. Here the polarization effect on the Fe electron density induced by $\mathrm{Cu}^{2+}$ is produced over the two-atomic cyano ligands $(\mathrm{CN})$. In $[\mathrm{Ni}($ cyclam $)]\left[\mathrm{Ru}(\mathrm{ox})(\mathrm{NO}) \mathrm{Cl}_{3}\right] \cdot 3 \mathrm{H}_{2} \mathrm{O}$ (2) the $\mathrm{Ni}^{2+}$ is acting over the mono-atomic chlorine ligand $\mathrm{Cl}(2)(\mathrm{Ni}-\mathrm{Cl}(2)=3.02 \AA)$ directly on the electron density of the $\mathrm{Ru}(\mathrm{Ru}-\mathrm{Ni}=4.89 \AA)$. We assume that this is the reason for the strong shift to higher decay temperatures (of SII) in this compound. In the Cs compound (1), on the other hand, the shortest distance between $\mathrm{Cs}(1)$ and $\mathrm{Cl}$ is $3.5 \AA$ and the decay temperatures are found at lower values. An interesting result is the short distance of $2.872 \AA$ between the fluorine atom $\mathrm{F}(6)$ of $\mathrm{PF}_{6}$ and the oxygen $\mathrm{O}(1)$ of the nitrosyl ligand in $[\mathrm{Ru}($ terpy $)(\mathrm{OH})(\mathrm{NO}) \mathrm{Cl}]\left[\mathrm{PF}_{6}\right](3)$, which is only $0.487 \AA$ longer than the $\mathrm{Ru}-\mathrm{Cl}$ bond inside of the cation. If the metastable states are explained by a structural change in the $\mathrm{Ru}-\mathrm{N}-\mathrm{O}$ region, as proposed by Carducci et al ${ }^{30}$, this interaction has to be broken, which should be detectable using vibrational spectroscopy by a frequency shift of the breathing and deformation modes of the $\left[\mathrm{PF}_{6}\right]-$ anion. The small shift of the decay- 
temperature maxima to lower values with respect to the compounds (1) and (2) is not a significant hint for this interaction. The local environment of the Ru-atom can also be responsible for the decrease. As found in a lot of other nitrosyl compounds ${ }^{15}$ the crystal water has no influence on the decay temperatures, so that only the cation can produce this shift, probably by hydrogen-bridge bonds of the cyclam to the oxalate or by polarization effects from the cation in the range of the $\mathrm{Ru}-\mathrm{N}-\mathrm{O}$ bonds.

We have presently no explanation concerning the effect of the nature of the ligand to the intensity of the populations of the states.

In summary we have found two extremely long-lived metastable states SI and SII in Ru compounds, using DSC. Their population and decay behavior is the same as found in $\mathrm{Fe}$ complexes, so that they are based on the same physical principle. Consequently, we can generally propose that these metastable states can be excited in nitrosyl-compounds, in which a charge transfer transition ( $\mathrm{d} \rightarrow \pi^{*} \mathrm{NO}$ ) exists, whereby the $\pi^{*} \mathrm{NO}$-orbital lies energetically between the d-states of the central atom. In order to get a long life time at room temperature a high activation energy and a low frequency factor is needed.

\section{ACKNOWLEDGMENT.}

Gratitude is expressed to Pr. S. Decurtins, to the Swiss National Science Foundation (Project No. 20-45750.95) and INTAS (No. 2000-0651) as well as to the Deutsche Forschungsgemeinschaft (Wo618/1-2) for financial support. 
Crystallographic data for the compounds $\mathbf{1}, \mathbf{2} \& \mathbf{3}$ in CIF format. This material is available free of charge from the Internet at http://pubs.acs.org

FIGURE CAPTIONS.

Figure 1 Asymmetric unit with atomic numbering scheme of $\mathrm{Cs}_{2}[\mathrm{Ru}$ ox $\left.)(\mathrm{NO}) \mathrm{Cl}_{3}\right]$ (1)

Figure 2 Antiparallel arrangement and the structure of $[\mathrm{Ru}$ ox $\left.)(\mathrm{NO}) \mathrm{Cl}_{3}\right]^{2}$

Figure 3 View of the crystal packing of $[\mathrm{Ni}($ cyclam $)]\left[\mathrm{Ru}(\mathrm{ox})(\mathrm{NO}) \mathrm{Cl}_{3}\right] \cdot 3 \mathrm{H}_{2} \mathrm{O}$ (2)

Figure 4 Exothermal heat flow $\dot{H}$ versus temperature of the metastable states SI and SII upon irradiation with unpolarized light for the three compounds (a) $\mathrm{Cs}_{2}[\mathrm{Ru}$ ox $\left.)(\mathrm{NO}) \mathrm{Cl}_{3}\right]$ (1), (b) $\left[\mathrm{Ni}(\right.$ cyclam) $]\left[\mathrm{Ru}(\mathrm{ox})(\mathrm{NO}) \mathrm{Cl}_{3}\right] \cdot 3 \mathrm{H}_{2} \mathrm{O}$ (2), (c) $[\mathrm{Ru}($ terpy $)(\mathrm{NO})(\mathrm{OH}) \mathrm{Cl}]\left[\mathrm{PF}_{6}\right]$ (3). The exposure has an amount of $\mathrm{Q}=2800 \mathrm{Ws} / \mathrm{cm}^{2}$

Figure 5 Temperature dependence of the lifetimes $\tau$ of SI/SII in $[\mathrm{Ni}($ cyclam $)]\left[\mathrm{Ru}(\mathrm{ox})(\mathrm{NO}) \mathrm{Cl}_{3}\right] \cdot 3 \mathrm{H}_{2} \mathrm{O}(2)$, calculated from the determined activation energy $E_{A}$ and the frequency factor $Z\left(\tau=Z \exp \left(-E_{\wedge} / k_{B} T\right)\right)$.

TABLES.

Table 1 Crystallographic data for compounds (1), (2) and (3)

Table 2 Fractional coordinates and isotropic displacement parameters for (1)

Table 3 Selected bond lengths $[\AA ̊]$ and angles [deg.] for compounds (1) and (2) 
Table 4 Activation energy and frequency factor for States I and II for some Ruthenium-Nitrosyl compounds

REFERENCES (Word Style “TF_References_Section”).

(1) Hauser, U.; Rohrweck, H. D.; Oestreich, V. Z. Phys. A 1977, 280, 17-25.

(2) a) Woike, Th.; Zöllner, H.; Krasser, W.; Haussühl, S. Solid State Comm. 1990, 73, $149-152$.

b) Woike, Th.; Haussühl, S. Solid State Comm. 1993, 86, 333-337.

(3) a) Fomitchev, D. V., Coppens, P. Inorg. Chem. 1996, 35, 7021-7026.

b) Kim, C., Novozhilova, I., Goodman, M.S., Bagley, K.A., Coppens, P. Inorg. Chem. 2000, 39, 5791-5795.

c) Kovalevsky, A., Bagley, K., Coppens, P. J. Am. Chem. Soc. 2002, 124, 9241-9248.

(4) a) Morioka, Y., Spectrochim. Acta, Part A 1994, 50A, 1499-1503.

b) Ookubo, K.; Morioka, Y.; Tomizawa, H.; Micki, E. J. Mol. Structure 1996, 379, 241247.

c) Morioka, Y.; Ishikawa, A., Tomizawa, H.; Micki, E-i J. Chem. Soc., Dalton Trans. 2000, $5,781-786$.

d) Kawano, M.; Ishikawa, A., Morioka, Y., Tomizawa, H.; Micki, E-I, Ohashi, Y. J. Chem. Soc., Dalton Trans. 2000, 5, 2425-2431.

(5) Guida, J. A.; Piro, O. E.; Schaiquevich, P. S.; Aymonino, P. J. Solid State Comm. 1997, 101, 4 71-475.

(6) Chen, L. X.; Bowman, M. K.; Wang, Z.; Montano, P. A.; Norris, J. R. J. Phys. Chem. 1994, 98, 9457-9464. 
(7) a) Woike, Th.; Krasser, W.; Zöllner, H.; Kirchner, W.; Haussühl, S. Z. Phys. D 1993, $25,351-356$.

b) Schaniel, D.; Schefer, J.; Delley, B.; Imlau, M.; Woike, T. Phys. Rev. B 2002, 66, 085103/1-085103/10.

(8) Zöllner, H.; Woike, Th.; Krasser, W.; Haussühl, S. Z. Krist. 1989, 188, 139-153.

(9) a) Guida, J. A.; Piro, O. E.; Aymonino, P. J. Solid State Comm. 1986, 57, 175-178.

b) Woike, Th.; Krasser, W.; Bechthold, P. S.; Haussühl, S. Phys. Rev. Lett. 1984, 53, 1767-1770.

(10) a) Woike, Th.; Kirchner, W.; Kim, H. S.; Haussühl, S.; Rusanov, V.; Angelov, V.; Bonchev, Ts. Hyperfine Interactions 1993, 77, 265-275.

b) Woike, T.; Imlau, M.; Angelov, V.; Schefer, J.; Delley, B. Phys. Rev. B 2000, 61, 12249-12260.

(11) Rüdlinger, M.; Schefer, J.; Chevrier, G.; Furrer, A.;Güdel, H. U.; Haussühl, S. Heger, G.; Schweiss, P.; Vogt, T.; Woike, Th.; Zöllner, H. Z. Phys. B 1991, 83, 125-130.

(12) Pressprich, M. R.; White, M. A.; Vekhter, Y.; Coppens, P. J. Am. Chem. Soc. 1994, $116,5233-5238$.

(13) Imlau, M.; Haussühl, S.; Woike, Th.; Schieder, R.; Angelov, V.; Rupp, R. A.; Schwarz, K. Appl. Phys. B 1999, 68, 877-885.

(14) Zöllner, H.; Krasser, W.; Woike, Th.; Haussühl, S. Chem. Phys. Lett. 1989, 161, 497501.

(15) Coppens, P.; Fomitchev, D. V. J. Chem. Soc., Dalton Trans. 1998, 865-872.

(16) The structure of this compound has already been described elsewhere : Bryan, C. D.; Bryan, T. A., Cordes, A. W.; Durham, B.; Jeter, D.; Yarbrough, J. C. J. Chem. Cryst. 1997, 27, 413-415. 
(17) Bosnich, B.; Tobe, M. L.; Webb, G. A. Inorg. Chem. 1965, 4, 1109-1112.

(18) Durig, J. R.; McAllister, W. A.; Willis, J. N.; Mercer, E. E. Spectr. Acta 1966, 22, 1091-1100.

(19) Murphy, W. R.; Takeuchi, K.; Barley, M. H.; Meyer, T. J. Inorg. Chem. 1986, 25, 1041-1053.

(20)Sullivan, B. P.; Calvert, J. M.; Meyer, T. J. Inorg. Chem. 1980, 19, 1404-1407.

(21) a) Haukka, M.; Venäläinen, T.; Ahlgren, M.; Pakkanen, T. A. Inorg. Chem. 1995, 34, 2931-2936; Haukka, M.; Ahlgren, M.; Pakkanen, T. A. J. Chem. Soc., Dalton Trans. 1996, 1927-1933; Honanen, P.; Haukka, M.; Ahlgren, M.; Pakkanen, T. A. Inorg. Chem. 1997, 36, 3794-3797.

b) Wong, K. Y.; Che, C. M.; Yip, W. H.; Wang, R. J.; Mak, T. C. J. Chem. Soc., Dalton Trans. 1992, 1417-1421.

c) Tomizawa, H.; Miki, E.; Mizumachi, K.; Ishimori, T. Bull. Chem. Soc. Jpn. 1994, 67, 1809-1815.

d) Ooyama, D.; Nagao, N.; Nagao, H.; Sugimoto, Y.; Howell, F. S.; Mukaida, M. Inorg. Chim. Acta 1997, 261, 45-52; Hirano, T; Ueda, K.; Mukaida, M.; Nagao, H.; Oi, T. J. Chem. Soc., Dalton Trans. 2001, 2341-2345.

(22)Sheldrick, G. M. SHELXS-97 Program for Crystal Structure Determination, Acta Cryst. 1990, 467

(23)Sheldrick, G. M. SHELXS-97 Program for Crystal Structure Refinement, University of Göttingen: Göttingen, Germany, 1997

(24) Spek, A. L., PLATON, Acta Crystallogr., 1990, S46, C-34.

(25)Fair, C. K., MolEN, an interaktive intelligent system for crystal structure analysis, Enraf-Nonius, Delft, 1990 
(26)a) Faure, R.; Duc, G.; Deloume, J. P. Acta Cryst. 1986, C42, 982-984.

b) Kaziro, R.; Hambley, T. W.; Binstead, R. A.; Beattie, J. K. Inorg. Chim. Acta 1989, $164,85-91$.

(27)Veal, J. T.; Hodgeson, D. J. Inorg. Chem. 1972, 6, 1420-1424.

(28) a) Decurtins, S.; Schmalle, H. W.; Pellaux, R.; Schneuwly, P.; Hauser, A. Inorg . Chem. 1996, 35, 1451-1460.

b) Decurtins, S.; Schmalle, H. W.; Schneuwly, P.; Ensling, J.; Gütlich, P.; J. Am. Chem. Soc. 1994, 116, 9521-9528.

(29) Prasad, L.; McAuley, A. Acta Cryst. 1983, C39, 1175-1177.

(30) Carducci, M. D.; Pressprich, M. R.; Coppens, P. J. Am. Chem. Soc. 1997, 119, 26692678.

(31) Mullica, D. F.; Tippin, D. B.; Sappenfield, E. L. J. Coord. Chem. 1992, 25, 175-182. 


\section{Tables}

Table 1. Crystallographic Data for compound 1, 2 and 3 (new measurement).

\begin{tabular}{|c|c|c|c|}
\hline & 1 & 2 & 3 \\
\hline Empirical formula & $\mathrm{C}_{2} \mathrm{Cl}_{3} \mathrm{Cs}_{2} \mathrm{NO}_{5} \mathrm{Ru}$ & $\mathrm{C}_{12} \mathrm{H}_{30} \mathrm{Cl}_{3} \mathrm{~N}_{5} \mathrm{NiO}_{8} \mathrm{Ru}$ & $\mathrm{C}_{15} \mathrm{H}_{12} \mathrm{ClN}_{4} \mathrm{O}_{2} \mathrm{PF}_{6} \mathrm{Ru}$ \\
\hline Formula weight $M$ & 591.27 & 638.54 & 561.78 \\
\hline Crystal system & Triclinic & Triclinic & monoclinic \\
\hline Space group & P-1(No. 2) & P-1 (No. 2) & $\mathrm{P} 2 / \mathrm{c}($ No. 14$)$ \\
\hline$a(\check{A})$ & $6.8497(7)$ & $9.111(2)$ & $9.688(2)$ \\
\hline$b(\check{A})$ & 7.2981(8) & $10.005(2)$ & $13.936(3)$ \\
\hline$c(\check{\mathrm{A}})$ & $12.7495(14)$ & $15.443(3)$ & $14.544(3)$ \\
\hline$\alpha$ (deg.) & $87.540(13)$ & $89.69(3)$ & \\
\hline$\beta$ (deg.) & $80.048(13)$ & $73.22(3)$ & $105.86(3)$ \\
\hline$\gamma($ deg. $)$ & $67.762(12)$ & $64.27(3)$ & \\
\hline$V\left(\AA^{3}\right)$ & $580.89(11)$ & $1202.4(4)$ & $1888.9(7)$ \\
\hline $\mathrm{Z}$ & 2 & 2 & 4 \\
\hline Temperature (K) & $223(2)$ & $295(2)$ & $296(2)$ \\
\hline $\begin{array}{l}\text { Calculated density / } \\
\qquad \mathrm{gcm}^{3}\end{array}$ & 3.380 & 1.764 & 1.97 \\
\hline$\lambda / \AA$ & 0.71073 & 0.71073 & 0.71073 \\
\hline$\mu,\left(\mathrm{mm}^{-1}\right)$ & 8.208 & 1.790 & 1.135 \\
\hline $\begin{array}{c}\text { Final } R_{1} \mathrm{a}, \mathrm{w} R_{2} \mathrm{~b} \\
\text { indices }\end{array}$ & $0.0258,0.0543$ & $0.0404,0.0891$ & $0.0448,0.1156$ \\
\hline
\end{tabular}


$R_{1}$, w $R_{2}$ indices

(all data)

a $R_{1}$ factor definition: $R 1=\sum\left(|| \mathrm{F}_{\mathrm{O}}|-| \mathrm{F}_{\mathrm{C}} \mid \mathrm{I}\right) / \sum\left|\mathrm{F}_{\mathrm{O}}\right|$

b SHELXL-97 $\mathrm{wR}_{2}$ factor definition: $\mathrm{wR}_{2}=\left[\sum \mathrm{w}\left(\mathrm{F}_{\mathrm{O}}^{2}-\mathrm{F}^{2}\right)^{2 / \Sigma} \mathrm{w}\left(\mathrm{F}_{\mathrm{O}}{ }^{2}\right)^{2}\right]^{1 / 2}$.

Weighting scheme: $w=1 /\left[\sigma^{2}\left(F_{O}\right)^{2}+(n p)^{2}+p\right], p=\left(\max \left(F_{o}^{2}\right)+2 F_{c}^{2}\right) / 3$. 
Table 2. Fractional Coordinates $\left(\mathrm{x} 10^{4}\right)$ and Equivalent Isotropic Displacement Parameters $\left(\AA^{2} \times 10^{3}\right)$ for 1 .

\begin{tabular}{|c|c|c|c|c|}
\cline { 2 - 5 } \multicolumn{1}{c|}{} & $\mathrm{x}$ & $\mathrm{y}$ & $\mathrm{z}$ & $\mathrm{U}_{\text {(eq) }}$ \\
\hline $\mathrm{Cs}(1)$ & $3170(1)$ & $8486(1)$ & $10868(1)$ & $23(1)$ \\
\hline $\mathrm{Cs}(2)$ & $-4326(1)$ & $6685(1)$ & $6460(1)$ & $24(1)$ \\
\hline $\mathrm{Ru}(1)$ & $1945(1)$ & $3058(1)$ & $7067(1)$ & $14(1)$ \\
\hline $\mathrm{Cl}(1)$ & $2535(2)$ & $458(2)$ & $8282(1)$ & $23(1)$ \\
\hline $\mathrm{Cl}(2)$ & $5584(2)$ & $1771(2)$ & $6273(1)$ & $25(1)$ \\
\hline $\mathrm{Cl}(3)$ & $1244(2)$ & $5904(2)$ & $6000(1)$ & $22(1)$ \\
\hline $\mathrm{N}(1)$ & $1191(6)$ & $1713(5)$ & $6224(3)$ & $18(1)$ \\
\hline $\mathrm{O}(1)$ & $686(7)$ & $775(5)$ & $5729(3)$ & $36(1)$ \\
\hline $\mathrm{O}(2)$ & $-1055(5)$ & $4440(4)$ & $7921(2)$ & $18(1)$ \\
\hline $\mathrm{O}(3)$ & $2651(5)$ & $4592(4)$ & $8128(2)$ & $20(1)$ \\
\hline $\mathrm{O}(4)$ & $1070(6)$ & $6880(6)$ & $9428(3)$ & $35(1)$ \\
\hline $\mathrm{O}(5)$ & $-2861(6)$ & $6972(5)$ & $9057(3)$ & $33(1)$ \\
\hline $\mathrm{C}(1)$ & $-1186(7)$ & $5795(6)$ & $8588(3)$ & $20(1)$ \\
\hline $\mathrm{C}(2)$ & $999(8)$ & $5800(6)$ & $8748(3)$ & $19(1)$ \\
\hline
\end{tabular}

$U_{(e)}$ is defined as one third of the trace of the orthogonalized $U_{\mathrm{ij}}$ tensor. 
Table 3 : Selected bond Lengths $[\AA]$ and Angles [deg] for $\mathbf{1}$.

$\begin{array}{cccc}\mathrm{Ru}(1)-\mathrm{N}(1) & 1.746(4) & \mathrm{Cs}(1)-\mathrm{O}(2)^{\# 2} & 3.213(3) \\ \mathrm{Ru}(1)-\mathrm{O}(3) & 2.021(3) & \mathrm{Cs}(1)-\mathrm{O}(3)^{\# 4} & 3.321(3) \\ \mathrm{Ru}(1)-\mathrm{O}(2) & 2.044(3) & \mathrm{Cs}(1)-\mathrm{O}(4) & 3.031(4) \\ \mathrm{Ru}(1)-\mathrm{Cl}(1) & 2.3549(11) & \mathrm{Cs}(1)-\mathrm{O}(4)^{\# 3} & 3.585(4) \\ \mathrm{Ru}(1)-\mathrm{Cl}(2) & 2.3579(11) & \mathrm{Cs}(1)-\mathrm{O}(5)^{\# 1} & 3.118(3) \\ \mathrm{Ru}(1)-\mathrm{Cl}(3) & 2.3717(11) & \mathrm{Cs}(1)-\mathrm{O}(5)^{\# 3} & 3.245(4) \\ \mathrm{N}(1)-\mathrm{O}(1) & 1.131(5) & \mathrm{Cs}(1)-\mathrm{Cl}(1)^{\# 2} & 3.6556(13) \\ \mathrm{O}(2)-\mathrm{C}(1) & 1.300(5) & \mathrm{Cs}(1)-\mathrm{Cl}(1)^{\# 4} & 3.6492(13) \\ \mathrm{O}(5)-\mathrm{C}(1) & 1.213(6) & \mathrm{Cs}(1)-\mathrm{Cl}(1)^{\# 5} & 3.5711(11) \\ \mathrm{O}(3)-\mathrm{C}(2) & 1.295(5) & \mathrm{Cs}(1)-\mathrm{Cl}(2)^{\# 4} & 3.8654(13) \\ \mathrm{O}(4)-\mathrm{C}(2) & 1.216(5) & \mathrm{Cs}(2)-\mathrm{O}(2) & 3.095(3) \\ & & \mathrm{Cs}(2)-\mathrm{O}(3)^{\# 7} & 3.426(3) \\ & & \mathrm{Cs}(2)-\mathrm{O}(5) & 3.659(4) \\ & & \mathrm{Cs}(2)-\mathrm{Cl}(1)^{\# 8} & 3.4560(13) \\ & & \mathrm{Cs}(2)-\mathrm{Cl}(2)^{\# 7} & 3.6285(12) \\ & & \mathrm{Cs}(2)-\mathrm{Cl}(2)^{\# 8} & 3.6872(11) \\ & & \mathrm{Cs}(2)-\mathrm{Cl}(2)^{\# 9} & 3.7572(13) \\ & & \mathrm{Cs}(2)-\mathrm{Cl}(3) & 3.5827(12) \\ & & \mathrm{Cs}(2)-\mathrm{Cl}(3)^{\# 7} & 3.4392(12) \\ & & \mathrm{Cs}(2)-\mathrm{Cl}(3)^{\# 9} & 3.6138(13)\end{array}$

Angles [deg]

$\begin{array}{cccc}\mathrm{N}(1)-\mathrm{Ru}(1)-\mathrm{O}(3) & 175.79(14) & \mathrm{O}(2)-\mathrm{Ru}(1)-\mathrm{Cl}(2) & 170.25(9) \\ \mathrm{N}(1)-\mathrm{Ru}(1)-\mathrm{O}(2) & 95.48(14) & \mathrm{Cl}(1)-\mathrm{Ru}(1)-\mathrm{Cl}(2) & 90.98(4) \\ \mathrm{O}(3)-\mathrm{Ru}(1)-\mathrm{O}(2) & 81.05(12) & \mathrm{N}(1)-\mathrm{Ru}(1)-\mathrm{Cl}(3) & 95.33(11) \\ \mathrm{N}(1)-\mathrm{Ru}(1)-\mathrm{Cl}(1) & 89.74(11) & \mathrm{O}(3)-\mathrm{Ru}(1)-\mathrm{Cl}(3) & 86.91(9) \\ \mathrm{O}(3)-\mathrm{Ru}(1)-\mathrm{Cl}(1) & 87.84(9) & \mathrm{O}(2)-\mathrm{Ru}(1)-\mathrm{Cl}(3) & 87.26(9) \\ \mathrm{O}(2)-\mathrm{Ru}(1)-\mathrm{Cl}(1) & 89.09(9) & \mathrm{Cl}(1)-\mathrm{Ru}(1)-\mathrm{Cl}(3) & 174.01(4) \\ \mathrm{N}(1)-\mathrm{Ru}(1)-\mathrm{Cl}(2) & 94.27(12) & \mathrm{Cl}(2)-\mathrm{Ru}(1)-\mathrm{Cl}(3) & 91.81(4) \\ \mathrm{O}(3)-\mathrm{Ru}(1)-\mathrm{Cl}(2) & 89.21(9) & \mathrm{Ru}(1)-\mathrm{N}(1)-\mathrm{O}(1) & 175.87(4)\end{array}$

Symmetry transformations used to generate equivalent atoms:

$\# 1 \mathrm{x}+1, \mathrm{y}, \mathrm{z}$ \#2 -x,-y+1,-z+2 \#3 -x,-y+2,-z+2 -x+1,-y+1,-z+2 \#5 x,y+1,z $\# 6-x+1,-y+2,-z+2 ~ \# 7 x-1, y, z$ \#8 $x-1, y+1, z$ \#9 $-x,-y+1,-z+1{ }^{* 10} x+1, y-1, z$ \#11 x,y-1,z 
Table 4 Activation energy and frequency factor for States I and II for some Ruthenium-Nitrosyl compounds

\begin{tabular}{|c|c|c|c|c|c|}
\hline Compounds & $\begin{array}{c}\text { Referenc } \\
\text { e }\end{array}$ & $\begin{array}{l}\text { Activation } \\
\text { energy } \\
(\mathrm{eV})\end{array}$ & $\begin{array}{l}\text { Frequency } \\
\text { factor } \\
\left(\mathrm{s}^{-1}\right)\end{array}$ & $\begin{array}{l}\text { Activation } \\
\text { energy } \\
(\mathrm{eV})\end{array}$ & $\begin{array}{l}\text { II } \\
\text { Frequency } \\
\text { factor } \\
\left(\mathrm{s}^{-1}\right)\end{array}$ \\
\hline (1) $\mathrm{Cs}_{2}\left[\mathrm{Ru}(\mathrm{ox})(\mathrm{NO}) \mathrm{Cl}_{3}\right]$ & & 0.60 & $2.5 \cdot 10^{13}$ & 0.46 & $5 \cdot 10^{12}$ \\
\hline (2) $[\mathrm{Ni}($ cyclam $)]\left[\mathrm{Ru}(\mathrm{ox})(\mathrm{NO}) \mathrm{Cl}_{3}\right] \cdot 3 \mathrm{H}_{2} \mathrm{O}$ & & 0.55 & $6 \cdot 10^{11}$ & 0.44 & $2 \cdot 10^{10}$ \\
\hline (3) $[\mathrm{Ru}($ terpy $)(\mathrm{OH})(\mathrm{NO}) \mathrm{Cl}]\left[\mathrm{PF}_{6}\right]$ & & 0.44 & $3 \cdot 10^{10}$ & 0.46 & $1.5 \cdot 10^{14}$ \\
\hline$c i s-\mathrm{K}\left[\mathrm{Ru}(\mathrm{ox})_{2}(\mathrm{en})(\mathrm{NO})\right]$ & $4 \mathrm{c}$ & 0.45 & $4.1 \cdot 10^{7}$ & & \\
\hline cis-K $\left[\mathrm{Ru}(\mathrm{ox})_{2}(\mathrm{en})(\mathrm{NO})\right] 3 \mathrm{H}_{2} \mathrm{O}$ & $4 \mathrm{c}$ & 0.46 & $1.1 \cdot 10^{\circ}$ & & \\
\hline cis-[Ru(Hox $\left.)(\mathrm{en})_{2}(\mathrm{NO})\right] \mathrm{Cl}_{2} \cdot \mathrm{EtOH}$ & $4 \mathrm{c}$ & 0.53 & $7.6 \cdot 10^{8}$ & & \\
\hline$c i s-[\mathrm{Ru}(\mathrm{Hox})(\mathrm{ox})(\mathrm{en})(\mathrm{NO})]$ & $4 \mathrm{c}$ & 0.46 & $1.1 \cdot 10^{6}$ & & \\
\hline trans $-\left[\mathrm{Ru}(\mathrm{Hox})(\mathrm{en})_{2}(\mathrm{NO})\right] \mathrm{Cl}_{2}$ & $4 \mathrm{c}$ & 0.67 & $1.3 \cdot 10^{9}$ & & \\
\hline trans-[RuCl(en) $\left.)_{2} \mathrm{NO}\right] \mathrm{Cl}_{2}$ & $4 \mathrm{~b}$ & 0.69 & $1.7 \cdot 10^{11}$ & & \\
\hline cis-[RuCl(en) $\left.{ }_{2} \mathrm{NO}\right] \mathrm{Cl}_{2}$ & $4 \mathrm{~b}$ & 0.46 & $1.7 \cdot 10^{8}$ & & \\
\hline trans $-\left[\mathrm{RuBr}(\mathrm{en})_{2} \mathrm{NO}\right] \mathrm{Br}_{2}$ & $4 \mathrm{~b}$ & 0.53 & $5.2 \cdot 10^{8}$ & & \\
\hline cis-[RuBr(en) $\left.)_{2} \mathrm{NO}\right] \mathrm{Br}_{2}$ & $4 \mathrm{~b}$ & 0.36 & $3.7 \cdot 10^{5}$ & & \\
\hline$\left[\mathrm{RuCl}_{3}(\mathrm{en}) \mathrm{NO}\right]($ fac- and $m e r-)$ & $4 \mathrm{~b}$ & 0.27 & $5.2 \cdot 10^{3}$ & & \\
\hline trans- $\left[\mathrm{Ru}\left(\mathrm{H}_{2} \mathrm{O}\right)(\mathrm{en})_{2} \mathrm{NO}\right] \mathrm{Cl}_{3}$ & $4 \mathrm{~b}$ & 0.67 & $4.4 \cdot 10^{9}$ & & \\
\hline $\mathrm{K}_{2}\left[\mathrm{Ru}\left(\mathrm{NO}_{2}\right)_{4}(\mathrm{NO})(\mathrm{OH})\right]$ & $2 \mathrm{~b}$ & 0.65 & $3.6 \cdot 10^{14}$ & 0.47 & $3.8 \cdot 10^{12}$ \\
\hline $\mathrm{K}_{2}\left[\mathrm{RuCl}_{5} \mathrm{NO}\right]$ & $2 \mathrm{a}$ & 0.71 & $3 \cdot 10^{15}$ & 0.47 & $5 \cdot 10^{15}$ \\
\hline $\mathrm{Na}_{2}\left[\mathrm{Fe}(\mathrm{CN})_{5}(\mathrm{NO})\right] \cdot 2 \mathrm{H}_{2} \mathrm{O}$ & 8 & 0.70 & $5 \cdot 10^{15}$ & 0.50 & $8 \cdot 10^{14}$ \\
\hline
\end{tabular}


Figures

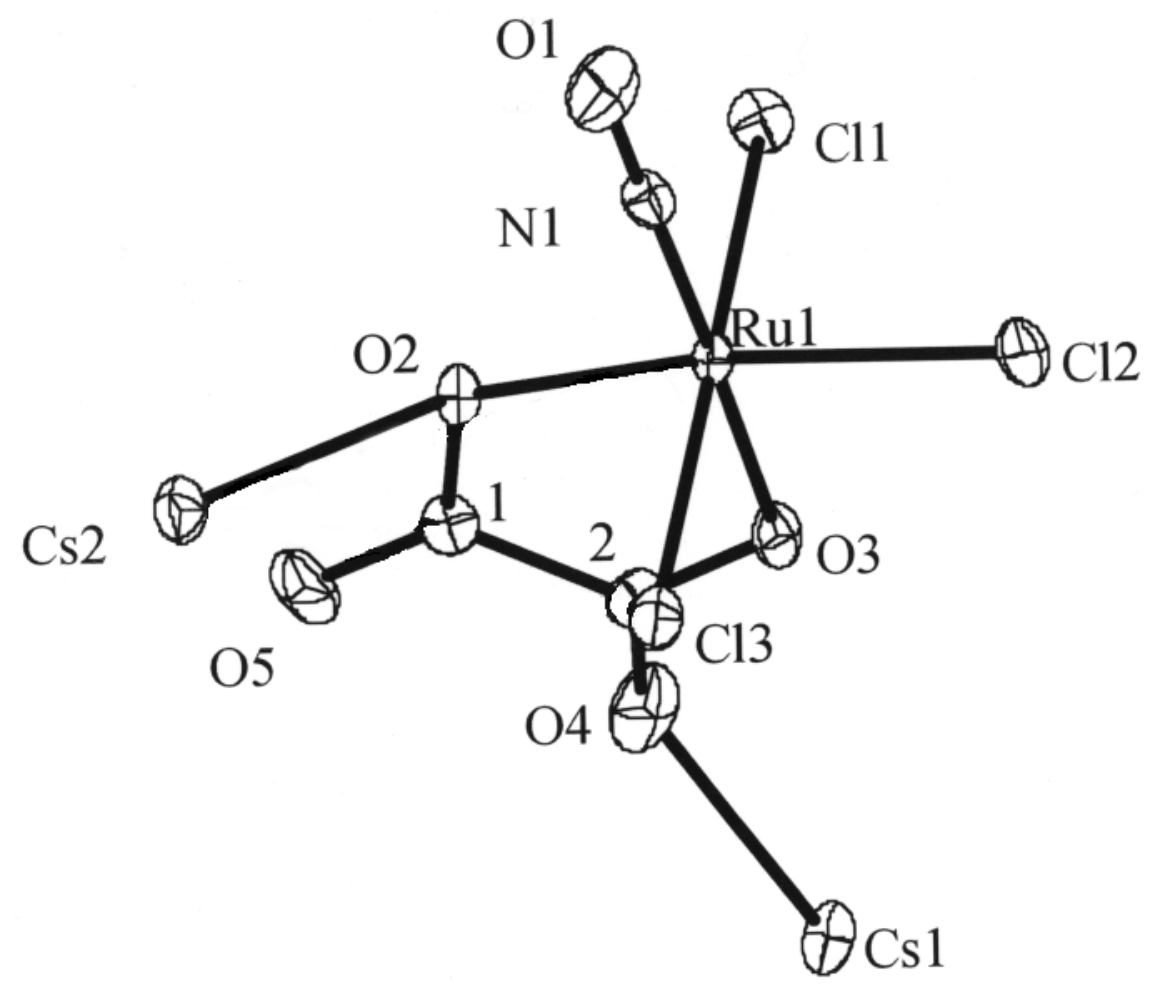

Figure 1 
Figure 2

Figure 3 


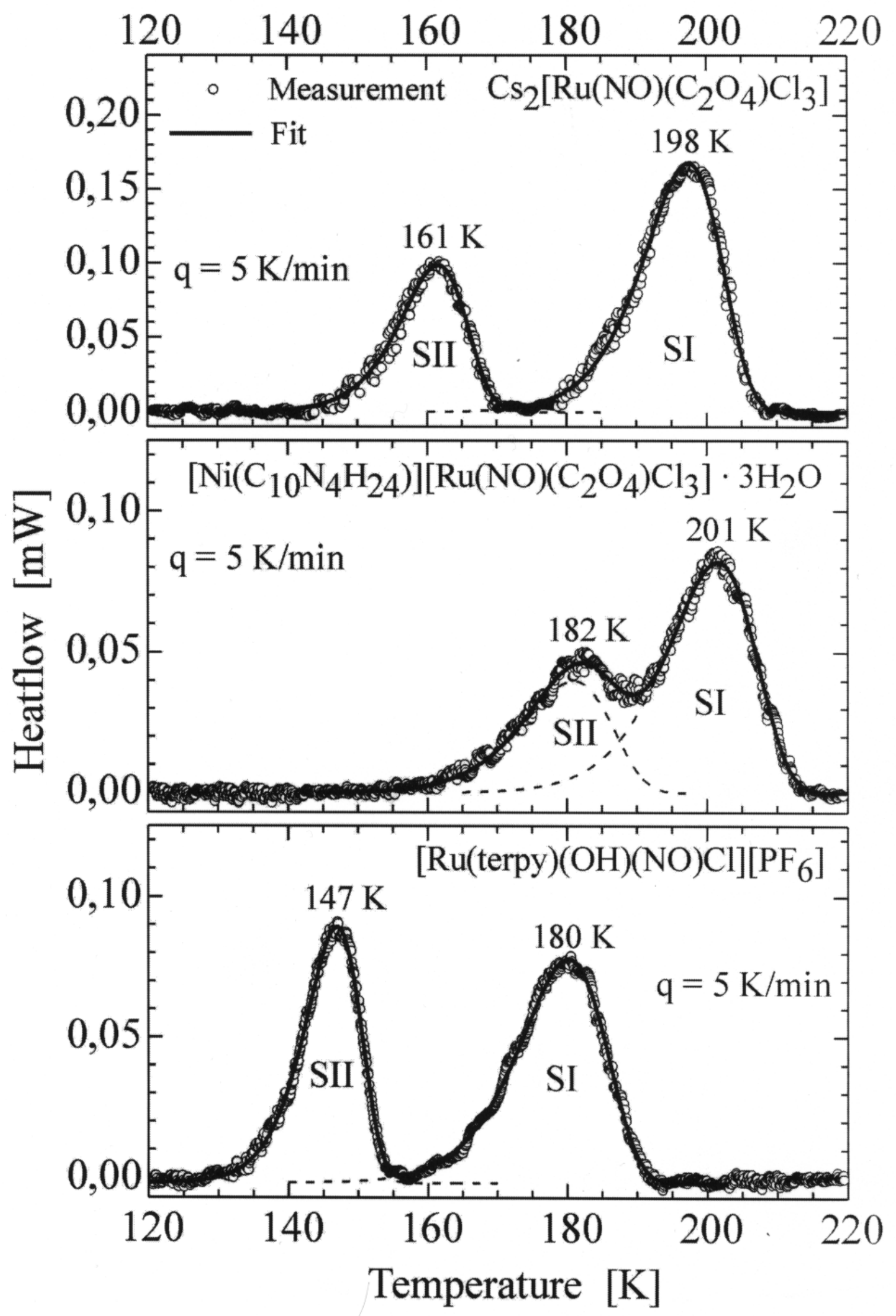

Figure 4 
(2)

$1 \cdot 18$

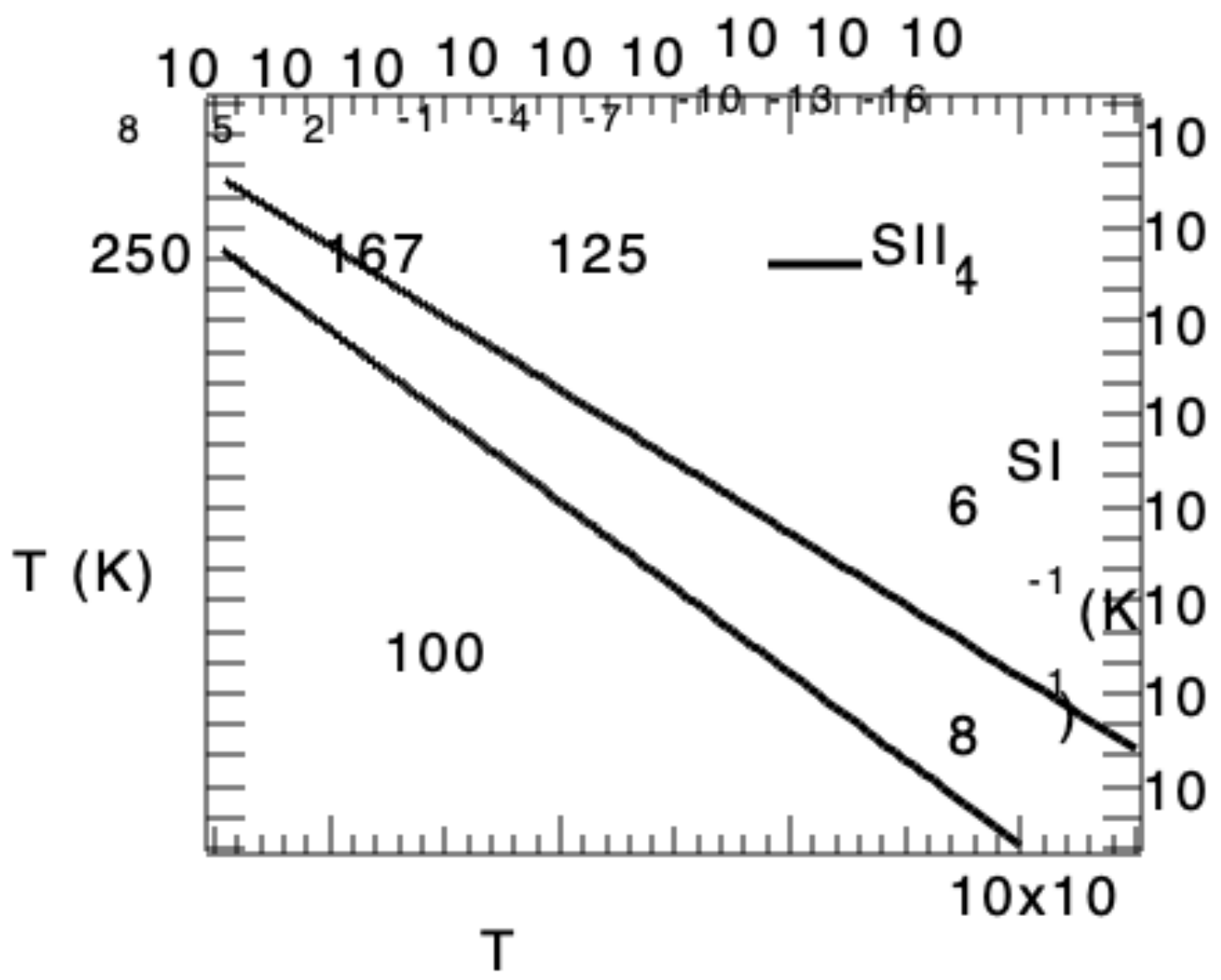

$-3$

Figure 5 